IBAD Sosyal Bilimler Dergisi

IBAD Journal of Social Sciences

dergipark.org.tr/ibad

IBAD, 2021; (11): 1-18

DOI: $10.21733 /$ ibad.897521

Özgün Araştırma / Original Article

\title{
Turizm Tüketicilerinin Sosyal Paylaşım Siteleri İle Otel Seçimleri Arasındaki İlişkiye Yönelik Ampirik Bir Çalışma
}

\section{An Empirical Study on the Relationship Between Tourism Consumers Social Sharing Sites and Hotel Choices}

\section{Damla Erdem ${ }^{*}$ \\ Azize Hassan ${ }^{2}$ \\ * Sorumlu yazar \\ Corresponding author}

${ }^{1}$ Arş. Gör., Kırklareli Üniversitesi, Türkiye Res. Assist., Kırklareli University, Turkey damlaerdem@klu.edu.tr ORCID ID 0000-0001-9792-7109

${ }^{2}$ Prof. Dr., Ankara Hacı Bayram Veli Üniversitesi, Türkiye Prof. Dr., Ankara Hacı Bayram Veli University, Turkey, azize.hassan@hbv.edu.tr ORCID ID 0000-0003-2509-1415

Makale geliş tarihi / First received : 15.03.2021 Makale kabul tarihi / Accepted : $\quad$ 24.04.2021

\author{
Bilgilendirme / Acknowledgement: \\ Yazarlar aşağıdaki billgillen dirmeleri yapmaktadırlar: \\ 1- Araştırma, birinci yazarın tezinden türetilmiş ve ikinci yazarın danışmanlığında gerçekleşmiştir. \\ 2- Bu çalışma, “Turizm Tüketicilerinin Sosyal Paylaşim Sitelerine Yönelik Algılarının Otel Seçimi İle İlişkisi” başlıklı \\ yüksek lisans tezinden üretilmiştir. \\ 3- Makalenin yazarları arasında çıkar çatışması bulunmamaktadır. \\ 4- Araştırma verileri 2020 yılı öncesinde toplanmıştır. \\ 5- Bu makalede araştırma ve yayın etiğine uyulmuştur.
}

This article was checked by Turnitin. Similarity Index 7\%

\section{Atıf bilgisi / Citation:}

Erdem, D., Hassan, A. (2021). Turizm tüketicilerinin sosyal paylaşım siteleri ile otel seçimleri arasındaki ilişkiye yönelik ampirik bir çalışma. IBAD Sosyal Bilimler Dergisi, (11), 1-18. 
ÖZ

Sosyal medyaya olan talebin gitgide artması, sosyal paylaşım sitelerinin ön plana çıkmasına imkân sağlamıştır. Bu durumla birlikte, kullanıcıların çoğu sosyal paylaşım sitelerini artık bilgi aracı olarak da nitelendirebilmektedir. Yaşamın birçok noktasında yer edinen sosyal medya, turizm alanı için de verimli bir ortam sunmaktadır. Turizm, dinamik ve yeniliğe açık bir endüstridir. Bu bakımdan çoğu otel işletmelerinin, turizm tüketicilerinin sosyal medyaya olan eğiliminin artacağını ön görmesi, sosyal medya sayesinde reklam ve pazarlama gibi kampanyaların daha çok kişiye ulaşmasında fayda sağlamıştır.Video, görsel, işitsel, metinsel gibi farklı boyutlarda içerik bulunduran popüler sosyal paylaşım sitelerinden olan Facebook ve Instagram'ın, turizm tüketicilerinin otel seçimleri için bilgi edindiği kaynaklar arasında olduğu söylenebilir. Turizm tüketicilerinin seyahat ettikleri yerler ve konakladıkları otellerden fotoğraflar paylaşması diğer potansiyel turizm tüketicilerini de etkilemekte ve merak duygusu uyandırmaktadır. Dolayısıyla bu durum turizm tüketicilerinin karar verme süreçlerinde etkili olabilmektedir. $\mathrm{Bu}$ önemden hareketle oluşturulan araştırmanın amacl; turizm tüketicilerinin sosyal paylaşım sitelerine ilişkin algılarının otel seçimine etkisinin değerlendirilmesidir. Araştırmada nicel araştırma yöntemlerinden veri toplama aracı olan anket tekniği kullanılmıştır. Araştırmanın verileri 377 katılımcıdan elde edilmiştir. Verilerin istatistiksel analizi SPSS paket programı kullanılarak yapılmıştır. Elde edilen verilerin değerlendirilmesi ile turizm tüketicileri tarafından sosyal paylaşım sitelerinin otel seçiminde etkili bir araç olarak kullanıldığı sonucu ile karşılaşılmıştır.

\section{Anahtar kelimeler}

Sosyal Medya, Sosyal Medya Pazarlaması ve Turizm, Sosyal Paylaşım Siteleri.

\section{ABSTRACT}

The increasing demand for social media has enabled social sharing websites to be highlighted. With this situation, most of the users might qualify social sharing websites as information tools. Social media that has gained an important position in various aspects of life also offers an efficient environment for the tourism field. Tourism is a dynamic sector with openness to innovation. In this sense, tourism managements' prediction towards the increasing tendency to social media by tourism consumers has contributed to the campaigns such as advertisement and marketing to reach a higher number of individuals via social media. Facebook and Instagram which are among the most popular social sharing websites with different content options such as video, images, audio and text are among the resources that tourism consumers obtain information for hotel selection. The tourism consumers sharing of images of the places they have visited and hotels they have accommodates influence the other potential tourism consumers and increase interest among them. Therefore, this might influence the decision-making process of the tourism consumer. Accordingly, the purpose of this study is to assess the effects of tourism consumers perception of social sharing websites on the hotel selection. This study adopts the survey method data collection technique among quantitative research methods. The data is collected from 377 participants. SPSS package program is used for the statistical analysis of the data. As the obtained data is analysed, it is found that tourism consumers use social sharing websites as an effective tool in hotel selection.

\section{Keywords}

Social media, Social Media Marketing and Tourism, Social Networking Sites. 


\section{GíRiş}

İnternet teknolojisindeki hızlı gelişmeler, bilgiye ulaşımı kolaylaştırmanın yanı sıra internet kullanıcılarının artmasına da zemin oluşturmaktadır. Bu nedenle internetin kullanıcılara sunduğu en yenilikçi oluşumu sosyal medya olarak ifade etmek mümkündür. Sosyal medya, bireylerin bilgi ihtiyaçlarını giderebildiği, içerikler hakkında yorum ve değerlendirme yapabildikleri ve sosyalleşebildikleri mecralar olarak kabul edilebilir. Video, görsel, işitsel, metinsel gibi farklı boyutlarda da içerik bulundurması da sosyal medyaya duyulan ilgiyi yoğunlaştırabilmektedir. Özellikle son yıllarda internet kullanımının artmış olması, sosyal medyayı günlük yaşantımızın vazgeçilmez noktası haline getirmiştir. Bu kapsamda sosyal medya etkisinin gün geçtikçe artması insanların sosyal platformlarda daha çok vakit geçirmeleri için zemin oluşturmakta ve tekdüze iletişim devrini sarsmaktadır. Global sosyal medya ajansı olan We Are Social'ın yayınlamış olduğu "2020 Global Dijital” raporuna göre; 7.676 milyar dünya nüfusunun, 4.57 milyarını internet kullanıcıları oluşturmaktadır. Aktif olarak sosyal medya kullanıcı sayısı ise 3.81 milyara ulaşmıştır. Türkiye'de de; 83.88 milyon ülke nüfusunun, 54 milyonunu aktif sosyal medya kullanıcıları oluşturmaktadır (dijilopedi.com, 2020). Yaşanılan çağın güç unsuru olan sosyal medya sayesinde bireyler ideolojilerini, daha rahat bir biçimde aktarabilecekleri, sosyalleşme ihtiyacını giderebilecekleri ve birçok kişiyle kolay ve hızlı bir biçimde iletişim kurabilecekleri çevrim içi gruplar oluşturmaktadırlar. Sosyal medya; turizm tüketicileri arasındaki etkileşimi kolaylaştıran, seyahatle ilgili görüşlerini, yorumlarını ve kişisel deneyimlerini paylaşmalarına yardımcı olan çevrim içi ağlar şeklinde ifade edilmektedir (Xiang ve Gretzel, 2010). Altınay Bor (2018, s. 11) ise sosyal medyayı güncel, çoklu kullanım ve paylaşıma imkân tanıyan platform olma özelliğinden dolayı geleneksel medya karşısında hızla güçlenen mecra olarak tanımlamaktadır.

Sosyal medya, daha çok kişiye eş zamanlı ulaşım imkânı vermekte ayrıca farkındalık meydana getirerek zengin içerikli pazarlama fikirleri oluşturulmasına firsat tanımaktadır. Bu durumun farkına varan otel işletmelerinin tüketicileri harekete geçirmek, etkili iletişim kurmak ve güven duygusunu aşılamak gibi amaçlarla sosyal medyada yaptığı paylaşımlar tanınırlığı artırmakla birlikte bir çekim gücü de oluşturmaktadır. Bununla birlikte turizm tüketicilerinin otel lehine sosyal medyada yaptıkları (\#) hashtag'li paylaşımlar popülerliği artırmakta ve potansiyel turizm tüketicilerine çekim gücü oluşturmaktadır. Böylelikle bu paylaşımlar turizm tüketicilerinin otel seçimi yaparken incelediği ve değerlendirdiği bilgi kaynağ 1 haline gelmektedir. Sosyal paylaşım sitelerinin, tüketici seçimlerini etkileme payının bulunması, otel işletmelerinin bu mecralarda mevcut ve potansiyel turizm tüketicilerine ulaşmak amaciyla yer edinmesini sağlamaktadır. Dolayısıyla sosyal paylaşım siteleri aracılığıyla yapılan otel tanıtımları, turizm tüketicileri tarafından o otelin tercih edilme oranını artırabilir.

Belirtilen önem kapsamında oluşturulan çalışmanın amacı, günümüzde en çok ziyaret edilen ve popülerlik kazanan Instagram ve Facebook sosyal paylaşım sitelerinde, otel tanitımlarına yönelik gerçekleştirilen pazarlama paylaşımlarını turizm tüketicilerinin bakış açısı ve algısına göre değerlendirmektir. Bu bağlamda, sosyal medya aracılı̆̆ı ile yapılan tanıtımların, otel işletmelerinin turizm tüketicileri tarafından tercih edilebilirlikleri konusunda da fikir sağlayacağı düşünülmektedir. Temel amacın yanı sıra araştırmada, turizm tüketicilerinin Instagram ve Facebook'tan edinilen bilgiler doğrultusunda yapılan yorum ve değerlendirmelerden hangi yönde etkilendikleri, hangi amaçla yararlandıkları ve hangi 
kullanım niyetiyle seçimde bulundukları gibi pazarlama açısından önemli sorulara cevap bulunması amaçlanmaktadır. Sosyal paylaşım araçlarından olan Instagram ve Facebook baz alınarak, turizm tüketicilerinin bakış açısı ile gerçekleştirilen araştırmalara ulusal literatürde yeterli düzeyde rastlanılmadığından, bu çalışma sadece Instagram ve Facebook üzerinden gerçekleştirilmiştir. Konu ile ilgili çalışmalar incelendiğinde sosyal medya alanında yapılan çoğu çalışmanın, otel işletmelerinin bakış açısına göre değerlendirildiği görülmektedir (Alagöz ve Dereli, 2020; Karamehmet ve Aydın, 2017; Buzlukçu ve Kılıç, 2015; Yılmazdoğan ve Özel, 2014). Söz konusu bu araştırma ise, turizm tüketicilerinin sosyal paylaşım sitelerine yönelik olan algısı boyutuyla ele alınacaktır. Günlük yaşamın bir parçası haline gelen sosyal paylaşım sitelerinin, turizm tüketicilerinin bakış açısına göre araştırılması büyük önem taşımakta ve elde edilecek bilgilerin alanda yapılan çalışmaların oldukça yeni olması sebebiyle gelecekte yapılacak benzer çalışmalara katkı sağlayacağı düşünülmektedir.

\section{KAVRAMSAL ÇERÇEVE}

\section{Sosyal Medya Pazarlaması}

Sosyal medyanın giderek güç ve önem kazanmasıyla birlikte, dijital dünyayla bütünleşmek kaçınılmaz bir hâl almaktadır. Günümüzde kullanım sıklığının giderek artmasının ardından işletmeler için de sosyal medya, pazarlama faaliyetleri bakımından önemli bir fırsat olmuştur (Fırat, 2017, s. 51). Sosyal medya, geleneksel medya araçlarına göre işletmelerin tüketiciyle iletişim halinde olmasını, yüksek etkili ve düşük maliyetli bir biçimde gerçekleştirmesini sağlamaktadır (Kaplan ve Haenlein, 2010, s. 65). Dolayısıyla sosyal medyanın kitlelerle etkili bağlantılar kurarak, kullanıcıları içerik paylaşımına teşvik etmesi, sosyal medya pazarlaması kavramının ortaya çıkmasında etkili olmuştur. Sosyal medya pazarlaması, "çevrim içi toplulukları, sosyal ağları, blog pazarlamacılığını ve daha fazlasını kullanarak pazarlama yapmaktır" (Neti, 2011, s. 3). Sosyal medya sadece tanıtımların yapıldığı bir mecra değil, ayrıca işletmelerin sosyal medya aracılığıyla ürünlerini, hizmetlerini, marka erişimi ve farkındalığını sunmak için kullandığı kanallar olarak nitelendirilebilir.

Oberoi, Patel ve Haon'e (2017) göre; sosyal medya pazarlaması, ilgi çekici paylaşımlar ile işletme popülerliğinin sosyal medyada kitlelere yansıtıldığı ortamların kullanılmasıdır. Başka bir tanıma göre; sosyal medya pazarlaması, sosyal medya araçlarını kullanarak tanıtım ve satış faaliyetlerinin gerçekleştirildiği ortamdaki uygulamalar olarak tanımlanabilir. Dolayısıyla sosyal medya pazarlaması, markaların bir araya getiremeyeceği topluluklara, sosyal medya araçları sayesinde erişim sağlayarak, onlarla bağlantı kurulmasında önemli rol oynamaktadır (Güçdemir, 2017, s. 107). Sosyal medya pazarlaması, tüketicilere hızlı ve kolay ulaşabilmeyi, tüketiciyle konuşulabilecek yeni ortamlar oluşturabilmeyi ve iletişimin sürekliliğini sağlamayı mümkün kılan faaliyetlerdir (Yeşildal, 2017). Böylelikle sosyal medya, katılım ve içerik oluşturma özelliklerinden dolayı, tüketicilerin söz hakkına sahip olduğu platform olanağı sunmaktadır. Gerçekleştirilen pazarlama faaliyetleri, tüketicilerin özgürce ortaya koydukları fikirler ile şekillenmekte, değerli ve daha güvenilir iletişim ortamının kurulmasına katkı sağlamaktadır.

Genel bir değerlendirme yapmak gerekirse, günümüzün sosyal medya pazarlaması, daha çok tüketicilerin etkileşimli deneyimine odaklanmaktadır (Liu, Zhang ve Yan Cao, 2018). Turizm endüstrisi de tanıtım ve reklam faaliyetleriyle eş zamanlı olarak, birçok turizm tüketicisine ulaşma ve tanınırlığı artırmak için sosyal medya paylaşım sitelerinde yerini almaktadır. Bu 
bağlamda tüketicilerin sosyal medyaya ayırdıkları zamanın arttığı düşüncesiyle, bu durumu fırsata çeviren otel işletmeleri de sosyal medya aracilığıyla pazarlama stratejilerini uygulayarak, turizm tüketicilerini birçok sosyal paylaşım siteleri aracılığıyla etkileyebilmektedir. Bu bakımdan sosyal medya pazarlaması, farkındalık yaratmak ve işletme tanınırlığını artırmak adına önemli bir rol üstlenmektedir. Aynı zamanda içeriğin sosyal medya aracılığı ile paylaşılması da daha fazla kullanıcı ile bağlantı ve etkileşim kurmayı kolay hale getirmektedir (Ahmad, Musa ve Harun, 2016). Öyle ki Youtube aracıllğı ile bir otel işletmesine ait tanıtım videosu, görsel içerik paylaşım platformu olan Instagram'dan fotoğraf paylaşımı, çeşitli etkinlik, haber ve iletişimi sağlayan Facebook'tan yazılı, görsel, işitsel metin, Twitter üzerinden ise \# hasgtag'li gündem paylaşımları oluşturularak her türlü kombinasyon meydana getirilmektedir. Bu açıdan bakıldığında turizm tüketicileri için sosyal medya aracılığıyla yapılan paylaşımlar, bilgi kaynağı oluşturmakta, davranış, alg1 ve değerlendirme sürecini etkileyebilmektedir.

\section{Sosyal Medya Pazarlaması Süreci ve Turizm}

Dijitalleşme ile birlikte, birçok endüstri için pratik ve etkili kullanım alanı oluşturan sosyal medya, turizm endüstrisine de çevrim içi pazarlama faaliyetlerinin gerçekleştirilmesinde verimli bir ortam sunmaktadır. Turizm, karşılıklı iletişim ve etkileşimin yoğun olduğu, teknolojik yenilikleri benimsemede aktif endüstriler arasında yer almaktadır. Her geçen gün sosyal medyaya olan ilginin biraz daha artması, özellikle turizm endüstrisi için, sosyal medyanın pazarlamaya dâhil olmasının teşvik edici nedenlerinden biridir.

Sosyal medya sayesinde turistik ürün/hizmet tanıtımları, pazarlama faaliyetleri, duyuru ve çeşitli kampanyalar daha geniş kitleler ile paylaşılabilmektedir. Bu bakımdan üretim ve tüketimin eş zamanlı olduğu, dinamik yapıya sahip turizm endüstrisi, sosyal medyanın pazarlama aracı olarak kullanılmasını zorunlu hale getirmektedir. Turizm endüstrisinin sosyal medyaya katılımı sosyal, ekonomik ve kültürel boyutta daha etkili bir kalkınma için önem arz etmektedir. Dolayısıyla sosyal medyada pazarlamaya dâhil olmak, turizm endüstrisi için göz ardı edilmemelidir. Bu bakımdan sosyal medya Zerfass, Moreno, Tench, Vercic, Verhoeven'e (2009, s. 60) göre şu faktörlerden oluşmaktadır:

- Sosyal medya yeniliğe açık ve anlaşılabilirdir,

-Tüketici odaklıdır,

-Yeni fikirlere teşvik eder ve iletişimi başlatır,

-Yeni ilişkiler ve ortaklıkların kurulmasına imkân tanır,

-Viral kampanyaların yürütülmesinde önemli rol oynar.

Sosyal medya; turizm kültürünün yanı sıra, turizm tüketicilerinin ve gezginlerin seyahat planlama sürecini ve turizm destinasyonları hakkında bilgi edinme yöntemlerini de değiştirmektedir. Bu nedenle sosyal medya pazarlaması, turizm endüstrisine; tüketici bilgisi toplama, tanınırlık, marka farkındalığı oluşturma ve iletişim kanalı gibi unsurları kapsayan yönetim akışına yeni bir boyut getirmektedir (Zeng ve Gerritsen, 2014, s. 33). Günümüzde, turizm tüketicileri sosyal medyayı, otel seçimlerine karar verirken artık önemli bir bilgi kanalı olarak görmektedir. Bu yönüyle sosyal medya; etkileşim, işbirliği, paylaşım ve iletişimde akıcılık özelliklerinden dolayı, turizm tüketicileri için kendilerini ifade edebilecekleri özgür bir ortam sunmaktadır. Karşılıklı iletişime önem veren turizm endüstrisi, etkileşim ve 
ulaşılabilirliği artırmak amacı ile sosyal medyada yer almanın önemli ölçüde fayda sağlayacağını görebilmektedir. Dolayısıyla “Hem turizm tüketicileri hem de turizm işletmeleri tarafından sosyal medya araçları, turizm endüstrisinde de ürün/hizmetlerin tanıtımı ve geri bildirim almada etkili bir yöntem olarak kullanılmaya başlanmıştır" (Eryılmaz ve Zengin, 2014, s. 48). Turizm tüketicilerinin sosyal paylaşım sitelerinde, tatilleri boyunca edindikleri tecrübeleri çeşitli biçimlerde (metin, görsel, video vb.) paylaşması, yakın çevresine ve potansiyel turizm tüketicilerine konaklamaları ile ilgili bilgiler sunmaktadır. Turizm tüketicileri tarafından yapılan bu paylaşımlar, sosyal paylaşım sitelerinin popülerliğini artırarak, potansiyel turizm tüketicilerinin konaklama isteğini artırmakta ve ilgisini çekmektedir (Arat ve Dursun, 2016, s. 118). Bu kapsamda turizm tüketicilerinin, otel seçimine karar verme sürecinde sosyal paylaşım sitelerinden etkilendikleri ifade edilebilir.

Turizm tüketicilerinin, turizm ürünleri hakkında karar verme sürecinde sosyal medya kullanımları 3 aşamada açıklanabilmektedir (Dwityas ve Briandana, 2017, s. 196):

-Seyahat öncesi aşama: (1) Seyahat etmek için, istek ve talebin oluşması, (2) seyahat edilecek varış yeri ve turizm faaliyetleri hakkında bilgilerin toplanması ve değerlendirilmesi, (3) seyahat kararını vermek ve seyahati gerçekleştirmek için gerekli olan uçak bileti, otel rezervasyonu gibi ürünlerin önceden satın alma işlemlerini içermektedir.

- Seyahat aşaması: Turizm tüketicilerinin, seyahat deneyimini elde ettikleri aşamadır. Konaklama, ulaşım, gıda gibi turizm kapsamındaki temel ihtiyaçların tüketimini içermektedir. Aynı zamanda bu aşamaya, turizm ürünleri çerçevesinde ihtiyaç duyulan diğer ek bilgilerin araştırılması da dâhil edilmektedir.

- Seyahat sonrası aşama: Seyahat faaliyetlerinin gerçekleştirildiği, kısacası seyahatin sonlandığı aşamadır. Bu süreç; deneyimlerin, turizm ürünlerinin, alınan seyahat kararı ve bilgi kaynaklarının bütünsel olarak değerlendirilmesini içermektedir. Değerlendirme sonucu, turizm tüketicilerinin memnun olup olmadıklarına göre bir sonraki seyahat kararlarını etkileyebilmesi bakımından önem arz etmektedir. Böylelikle bir turizm tüketicisinin edindiği deneyimler gelecekteki seyahatlerini planlamada yol gösterici olabilecektir.

Turizm tüketicileri, etkili ve hızlı iletişime imkân tanıyan sosyal medya sayesinde, birçok kişi ile doğrudan bağlantı kurabilmekte ve tatil deneyimlerini paylaşabilmektedir. Turizm endüstrisi, tanıtım ve pazarlama faaliyetlerini kitlelere ulaştırmada sosyal medya aracilığı ile daha aktif bir rol üstlenmektedir. Söz konusu bu durum turizm endüstrisinde yer alan işletmelerin sosyal medya ile işbirliği yapmasına yol açmaktadır. Seyahat öncesi turizm tüketicileri için sınırsız sayıda bilgi sunan sosyal medya, onlara konaklamak istedikleri oteli hayal etmek için fikir edinmeye yardımcı olmaktadır (Rathore, Joshi ve Ilavarasan, 2017, s. 752). Dolayısıyla, turizm tüketicilerinin sosyal medyayı hızla benimsemesi, turizm endüstrisinin sosyal medya pazarlamasına kayıtsız kalmaması gerektiğinin göstergesidir.

\section{YÖNTEM}

\section{Evren ve Örneklem}

Çalışmada, veri toplamak için anket tekniğinden yararlanılmıştır. Kullanılan ölçek 5'li likert tipinde derecelendirilmiştir. Gerçekleştirilen araştırma, turizm tüketicilerinin sosyal paylaşım sitelerini algılama yaklaşımlarını belirlemeyi ve değerlendirmeyi hedeflemesinden dolayı, bu çalışma betimleyici araştırma modelinin özelliğini yansıtmaktadır. Betimleyici araştırma, "ele 
alınan konu ya da etkinliklerin betimlemesini ve tasvirini sağlamayı amaçlayan araştırmalar" biçiminde ifade edilmektedir (bingol.edu.tr, 2020).

2019 yılı 15 Mart ve 15 Nisan tarihleri arasında araştırmanın uygulama aşaması gerçekleştirilmiştir. Ankete 377 kişi katılım sağlamıştır. Araştırmanın genel güvenirliliğini test etmek için kullanılan Cronbach Alfa değerinin 0,70 üzerinde olması ölçekteki maddelerin birbirleriyle tutarlı ve güvenirliliğinin yüksek olduğunu belirtmektedir (Yıldız ve Uzunsakal, 2018, s. 19). Bu çalışmada kullanılan anketin güvenirliği ise Cronbach Alfa test edilerek 0,942 değeri bulunmuştur. Dolayısıyla ölçeğin oldukça güvenilir olduğunu ifade etmek mümkündür.

\section{Veri Analizi}

Verilerin istatistiksel analizleri için SPSS 22.0 paket programı kullanılmıştır. Ölçek alt boyutlarının yaş, cinsiyet ve eğitim grupları üzerinden tanımlayıcı istatistikleri, anket soruları için yüzde-frekans analizi, eğitim ve yaş gruplarının çoklu değerlendirilmesinde ise tek yönlü varyans analizi ANOVA testi, cinsiyet grupları arasındaki değerlendirmede de Independent Sample T-testi kullanılmıştır. Çalışmada anlamlılık düzeyi $(\mathrm{p}<0,05)$ olarak kabul edilmiştir.

\section{Veri Toplama Aracı}

Bu araştırmada yer verilen ölçek için, Atadil'in (2011) yüksek lisans tez çalışmasında kullanmış olduğu ölçekten uyarlanarak faydalanılmıştır. Anket toplam 47 sorudan oluşmaktadır. Bunların 6 tanesi demografik sorulardan, geri kalanı ise turizm tüketicilerinin sosyal paylaşım sitelerine ilişkin algılarını değerlendirmeye yönelik hazırlanan sorulardan oluşmaktadır.

Anket alt boyutları 8 ayrı başlıktan oluşmaktadır. Bu başlıklar sırasıyla; bilgi edinme, paylaşım ve aidiyet, etkileşim ve güvenme, yararlanma, çelişki, kullanım, firmalara yönelik değerlendirme ve genel değerlendirme şeklinde kategorilere ayrılmaktadır. Anket formunun ilk bölümünde araştırmada daha sağlıklı sonuçlara ulaşılması açısından, kişilere yöneltilen 'Konaklayacağınız oteli seçmeden önce Facebook veya Instagram sitelerinden otellere yönelik inceleme yaptınız mı?' sorusu ile dikkat değerlendirilmesi yapılmıştır.

Anket sorularına katılımcılar tarafından 5'li likert ölçeği ile değerlendirilecek olan, “tamamen katılmiyorum"dan "tamamen katılıyorum"a doğru siralanan ifadelere cevap verilmesi istenmiştir.

\section{BULGULAR}

\section{Demografik Veriler}

Katılımcılara ait demografik özellikler Tablo 1 üzerinde verilmiştir. Tablo 1'de de belirtildiği gibi çalışmaya katılan kadın sayısı 208, erkek sayısı 169'dur. Ankete katılanların yaş dağılımı incelendiğinde, 21-30 yaş ve 31-40 yaş aralığının çoğunluk oluşturduğu gözlemlenmektedir. Katılımcıların büyük kısmının ise; ön lisans, lisans ve lisansüstü eğitim aldığını ifade etmek mümkündür. Kadın ve erkek katılımcıların Facebook ve Instagram sitelerini gün içinde \% 32,1 oranı ile (12 kez) ve üzerinde ziyaret ettiği saptanmıştır. Katılımcıların Facebook ve Instagram sayfalarına ayırdıkları zamana bakıldı̆̆ında ise büyük çoğunluğunun sosyal medyada \% 39,7 oranı ile günlük (1-2) saat zaman harcadığı görülmektedir. 
Tablo 1. Katılımcıların Demografik Özellikleri

\begin{tabular}{llc}
\hline Cinsiyet & $\mathbf{N}$ & $\mathbf{\%}$ \\
\hline Kadın & 208 & 55,2 \\
\hline Erkek & 169 & 44,8 \\
\hline Yaş & $\mathbf{N}$ & $\mathbf{\%}$ \\
\hline 20 Yaş ve Altı & 26 & 6,9 \\
\hline $21-30$ Yaş & 240 & 63,6 \\
\hline 31-40 Yaş & 72 & 19 \\
\hline $41-50$ Yaş & 23 & 6,1 \\
\hline 51 Yaş ve Üstü & 16 & 4,2 \\
\hline Ĕgitim Durumu & $\mathbf{N}$ & $\mathbf{\%}$ \\
\hline İlköğretim & 4 & 1,06 \\
\hline Lise & 29 & 7,69 \\
\hline Ön lisans & 71 & 18,83 \\
\hline Lisans & 238 & 63,12 \\
\hline Lisansüstü & 35 & 9,28 \\
\hline Gün İçerisinde Sosyal Paylaşım Sitelerini Ziyaret Sayısı & $\mathbf{N}$ & $\mathbf{\%}$ \\
\hline $1-3$ & 56 & 14,7 \\
\hline $4-6$ & 52 & 13,7 \\
\hline $7-9$ & 77 & 20,3 \\
\hline $10-11$ & 71 & 18,7 \\
\hline 12 ve üstü & 122 & 32,1 \\
\hline Gün İçerisinde Sosyal Paylaşım Sitelerine Ayırılan Zaman & $\mathbf{N}$ & $\mathbf{\%}$ \\
\hline 1 saatten az & 87 & 22,9 \\
\hline $1-2$ & 151 & 39,7 \\
\hline $3-5$ & 100 & 26,3 \\
\hline $6-9$ & 35 & 9,2 \\
\hline $10-14$ & 5 & 1,3 \\
\hline & & \\
\hline
\end{tabular}

\section{Anket Sorularının Yüzde Frekans Analizi}

Tablo 2. Anket İfadelerinin Yüzde Frekans Analizinin Cevap Dağ̆lımı

\begin{tabular}{|l|c|c|}
\hline İfadeler & $\mathbf{N}$ & $\mathbf{\%}$ \\
\hline BİLGI EDINME & & \\
\hline 1.Sosyal paylaşım siteleri, otel işletmeleri hakkında bilgi almamı sağlar. & 108 & 28,4 \\
\hline 2.Sosyal paylaşım siteleri, otel işletmelerinin web sitelerine ulaşmamı sağlar. & 139 & 36,6 \\
\hline $\begin{array}{l}\text { 3.Sosyal paylaşım sitelerindeki otel işletmeleri hakkında yapılan yorumlar, } \\
\text { istediğim seyahati planlamama yardımcı olur. }\end{array}$ & 112 & 29,5 \\
\hline PAYLAŞIM VE AİDiET & & \\
\hline $\begin{array}{l}\text { 4.Sosyal paylaşım sitelerinde, seyahat deneyimlerimi ve bu seyahatlerle ilgili } \\
\text { yorumlarımı paylaşmak hoşuma gider. }\end{array}$ & 82 & 21,6 \\
\hline $\begin{array}{l}\text { 5.Sosyal paylaşım siteleri, seyahatlere yönelik benimle benzer ilgilere sahip olan } \\
\text { insanlarla iletişim içinde kalmamı sağlar. }\end{array}$ & 62 & 16,3 \\
\hline \begin{tabular}{l} 
6.Sosyal paylaşım siteleri, bir gruba ait olduğumu hissettirir. \\
\hline
\end{tabular} & 39 & 10,3 \\
\hline
\end{tabular}




\begin{tabular}{|c|c|c|}
\hline $\begin{array}{l}\text { 7.Seyahatlerim esnasında konakladığım oteller ve gördüğüm yerler hakkında } \\
\text { deneyim ve yorumlarımı, sosyal paylaşım sitelerinde paylaşma isteği duyarım. }\end{array}$ & 65 & 17,1 \\
\hline $\begin{array}{l}\text { 8.Seyahat deneyimlerimi paylaşmak için sosyal paylaşım siteleri kolay kullanım } \\
\text { özelliğine sahiptir. }\end{array}$ & 112 & 29,5 \\
\hline \multicolumn{3}{|l|}{ ETKİLEŞIM VE GÜVENME } \\
\hline $\begin{array}{l}\text { 9.Sosyal paylaşım sitelerinde paylaşılan seyahatler hakkındaki deneyim ve } \\
\text { yorumları inandırıcı bulurum. }\end{array}$ & 49 & 12,9 \\
\hline 10.Turistlerin sosyal paylaşım sitelerindeki paylaşımlarını güvenilir bulurum. & 66 & 17,4 \\
\hline 11.Seyahat paylaşımlarımda hashtag kullanmak daha çok kişiye ulaşmamı sağlar. & 104 & 27,4 \\
\hline $\begin{array}{l}\text { 12.Sosyal paylaşım sitelerinde, otel işletmeleri hakkında yapılan yorumlardan } \\
\text { etkilenirim. }\end{array}$ & 104 & 27,4 \\
\hline $\begin{array}{l}\text { 13.Sosyal paylaşım sitelerinde bir otel işletmesinin sayfasını ziyaret ettikten } \\
\text { sonra, o otel işletmesinde konaklamayı düşünebilirim. }\end{array}$ & 90 & 23,7 \\
\hline \multicolumn{3}{|l|}{ YARARLANMA } \\
\hline $\begin{array}{l}\text { 14.Sosyal paylaşım sitelerinde otel işletmelerinin sayfalarındaki otel işletmesi } \\
\text { hakkındaki fotoğrafları görüntülerim. }\end{array}$ & 155 & 40,8 \\
\hline $\begin{array}{l}\text { 15.Sosyal paylaşım sitelerinde otel işletmelerinin sayfalarındaki otel işletmesi } \\
\text { hakkındaki videoları izlerim. }\end{array}$ & 136 & 35,8 \\
\hline 16.Hashtag'li paylaşımlar otel işletmelerine daha kolay ulaşmamı sağlar. & 106 & 27,9 \\
\hline 17.Sosyal paylaşım siteleri, yeni otel işletmelerini keşfetmeme yardımcı olur. & 132 & 34,7 \\
\hline $\begin{array}{l}\text { 18.Sosyal paylaşım sitelerinde, otel işletmelerinin satın almayı düşündüğüm } \\
\text { turistik ürün ve hizmetler hakkında yaptığı güzel teklifleri öğrenirim. }\end{array}$ & 89 & 23,4 \\
\hline $\begin{array}{l}\text { 19.Sosyal paylaşım sitelerinde konaklamayı düşündüğüm otel işletmelerinin } \\
\text { pazarlama kampanyalarını takip ederim. }\end{array}$ & 95 & 25,0 \\
\hline \multicolumn{3}{|l|}{ ÇELİŞKİ } \\
\hline $\begin{array}{l}\text { 20.Sosyal paylaşım sitelerinde otel işletmeleri hakkında faydalı bilgilere } \\
\text { ulaşmak çok uzun zaman almaktadır. }\end{array}$ & 25 & 6,6 \\
\hline $\begin{array}{l}\text { 21.Sosyal paylaşım sitelerinde, otel işletmeleri hakkında faydalı bilgilere ulaşmak } \\
\text { mümkün değildir. }\end{array}$ & 15 & 3,9 \\
\hline $\begin{array}{l}\text { 22.Sosyal paylaşım sitelerinde, diğer üyeler tarafından yorumlarımın } \\
\text { okunmaması için, otel işletmeleri hakkında yorumlarda bulunmuyorum. }\end{array}$ & 38 & 10,0 \\
\hline $\begin{array}{l}\text { 23.Sosyal paylaşım sitelerinde fotoğraflar ve videolara yorumlarda bulunmak } \\
\text { karmaşık işlemler gerektirir. }\end{array}$ & 19 & 5,0 \\
\hline 24.Sosyal paylaşım sitelerini güvenli bulmuyorum. & 36 & 9,5 \\
\hline $\begin{array}{l}\text { 25.Sosyal paylaşım sitelerinde otel işletmeleri hakkında edindiğim bilgi ve } \\
\text { yorumları inandırıcı bulmuyorum. }\end{array}$ & 24 & 6,3 \\
\hline \multicolumn{3}{|l|}{ KULLANIM } \\
\hline $\begin{array}{l}\text { 26.Sosyal paylaşım sitelerindeki beğendiğim otel işletmelerinin sayfalarını, } \\
\text { arkadaşlarımla paylaşırım. }\end{array}$ & 90 & 23,7 \\
\hline $\begin{array}{l}\text { 27.Bir otel işletmesi hakkında olumlu ya da olumsuz yorumlarımı sosyal } \\
\text { paylaşım sitelerinde arkadaşlarıma iletirim. }\end{array}$ & 85 & 22,4 \\
\hline $\begin{array}{l}\text { 28.Sosyal paylaşım sitelerinde otel işletmelerinin hayranı ya da takipçisi olarak, } \\
\text { bu otel işletmeleri hakkında yenilikleri öğrenirim. }\end{array}$ & 86 & 22,6 \\
\hline $\begin{array}{l}\text { 29.Sosyal paylaşım sitelerinde ilgi duyduğum otel işletmeleri için kurulmuş } \\
\text { gruplara üye olurum. }\end{array}$ & 31 & 8,2 \\
\hline $\begin{array}{l}\text { 30.Sosyal paylaşım sitelerinde, bir otel işletmesi ile doğrudan iletişime } \\
\text { geçebildiğim için, o otel işletmesini kendime daha yakın görürüm. }\end{array}$ & 94 & 24,7 \\
\hline $\begin{array}{l}\text { 31.Sosyal paylaşım sitelerinde turistik aktiviteler hakkında diğer üyelerin } \\
\text { yaptıkları yorum ve bilgilendirmelerden faydalandığım için, ben de kendimi }\end{array}$ & 50 & 13,2 \\
\hline
\end{tabular}




\begin{tabular}{|l|c|c|}
\hline yorum ve bilgi paylaşımında bulunmak adına sorumlu hissederim. & & \\
\hline FİRMALARA YÖNELIK DEĞERLENDİRME & 105 & 27,6 \\
\hline $\begin{array}{l}\text { 32.Sosyal paylaşım siteleri, otel işletmeleri ve turizm tüketicileri arasındaki } \\
\text { iletişimin artmasında olumlu etkiler yaratır. }\end{array}$ & 148 & 38,9 \\
\hline $\begin{array}{l}\text { 33.Sosyal paylaşım siteleri, otel işletmelerinin bilinirliğinin artmasında olumlu } \\
\text { etkiler yaratır. }\end{array}$ & 150 & 39,5 \\
\hline $\begin{array}{l}\text { 34.Otel işletmelerinin internet üzerinden yaptıkları pazarlama kampanyalarını, } \\
\text { sosyal paylaşım siteleri daha kolay duyurur. }\end{array}$ & 129 & 33,9 \\
\hline $\begin{array}{l}\text { 35.Sosyal paylaşım siteleri, otel işletmelerinin imajı üzerine olumlu etkiler } \\
\text { yaratır. }\end{array}$ & 98 & 25,8 \\
\hline $\begin{array}{l}\text { 36.Sosyal paylaşım sitelerinin varlığı sayesinde bir tüketici olarak kendimi daha } \\
\text { bilinçli hissederim. }\end{array}$ & 116 & 30,5 \\
\hline $\begin{array}{l}\text { 37.Sosyal paylaşım sitelerinde, arkadaşlarımın konaklamayı düşündüğüm otel } \\
\text { işletmeleri hakkında düşüncelerini öğrenmek beni mutlu eder. }\end{array}$ & 131 & 34,5 \\
\hline GENEL DEĞERLENDİRME & 118 & 31,1 \\
\hline $\begin{array}{l}\text { 38.Bir turizm tüketicisi olarak sosyal paylaşım sitelerinden otel işletmeleri } \\
\text { hakkında bilgi edinirim. }\end{array}$ & 122 & 32,1 \\
\hline $\begin{array}{l}\text { 39.Sosyal paylaşım siteleri, seyahat planlamamı yaparken konaklayacağım otel } \\
\text { işletmesinin seçimini etkiler. }\end{array}$ & 83 & 21,8 \\
\hline 40.Sosyal paylaşım siteleri, otel işletmeleri hakkında düşüncelerimi etkiler. & & \\
\hline $\begin{array}{l}\text { 41.Sosyal paylaşım sitelerinde konakladığım otel işletmesi hakkındaki } \\
\text { deneyimlerimi paylaşmaktan zevk alırım. }\end{array}$ &
\end{tabular}

Katılımcların, anket sorularına verdikleri yanıtlardan en yüksek değer ele alınarak, yüzdefrekans analizleri Tablo 2' de belirtilmiştir.

Sosyal medyanın erişim gücünün etkisi, katılımcıların "sosyal paylaşım siteleri, otel işletmelerinin web sitelerine ulaşmamı sağlar" ifadesine çoğunluğunun verdiği "tamamen katılıyorum" yanıtı ile görülmektedir. Turizm tüketicilerinin sosyal paylaşım sitelerindeki otel işletmeleri hakkında yapılan yorumlardan etkilendikleri ve bu sayede sosyal medya aracılığ istenilen seyahatin planlanmasında yardımcı olduğu sonucuna varılmıştır. Sosyal medyanın tüketicilere anlık olarak ileti oluşturma olanağını vermesi, seyahat etmeyi seven ve keşfettikleri yerleri diğer tüketicilerle paylaşmak isteyenlerin çokça tercih ettiği mecra olduğu ifade edilebilecektir. Buradan hareketle, seyahat deyimlerini paylaşanların düşüncelerinden elde edilen diğer bir nokta da, sosyal paylaşım sitelerinin kullanım kolaylığı sağladığını çoğunluğunun desteklenmesidir. Aynı zamanda "seyahat paylaşımlarımda hashtag kullanmak daha çok kişiye ulaşmamı sağlar" sorusuna verilen yanıtlar, turizm tüketicilerinin seyahat paylaşımlarına çeşitli hashtag'leri eklemesinin daha fazla kişiye ulaşılmasında etkili bir yöntem olduğu yönündedir.

Ankette elde edilen bulgulardan bir diğeri ise; turizm tüketicilerinin otel işletmeleri hakkında sayfada yer alan fotoğrafları görüntüledikleri ve videoları izledikleri sonucunun olumlu şekilde değerlendirilmesidir. Tüketiciler, sosyal paylaşım siteleri sayesinde faydalı bilgilere ulaşmanın mümkün olduğunu ifade etmektedir. Ayrıca turizm tüketicilerinin, sosyal paylaşım sitelerinde bulunan otel işletmeleri sayfalarında fikirlerini beyan etmekten çekinmedikleri açıkça söylenebilir. Facebook ve Instagram üzerinden bir otel işletmesinin imajını olumlu veya olumsuz yönde etkileyebilecek herhangi bir geri dönüşün turizm tüketicileri tarafından önemsendiği ve arkadaş çevresine iletmekten çekinmedikleri sonucuna varılmıştır. Böylelikle 
çelişki boyutunda yer verilen sosyal paylaşım sitelerinin güvenli olmadığına dair sorulan soruda da turizm tüketicileri tarafından tam aksinin ifade edildiği gözlemlenmektedir.

Tablo 3. Eğitim Grupları Üzerinden Ölçek Alt Boyutlarının Karşılaştırıldığı ANOVA Testi Sonuçları

\begin{tabular}{|c|c|c|c|c|c|c|c|c|c|c|c|}
\hline \multirow[b]{2}{*}{ Değişken } & \multirow[b]{2}{*}{ Grup } & \multirow[b]{2}{*}{$\mathbf{N}$} & \multirow[b]{2}{*}{$\bar{x}$} & \multirow[b]{2}{*}{$S$} & \multicolumn{6}{|c|}{ ANOVA } & \multirow{2}{*}{$\begin{array}{c}\text { Post- } \\
\text { hoc } \\
\text { (Tukey } \\
\text { ) }\end{array}$} \\
\hline & & & & & & KT & df & KO & $\mathbf{F}$ & $\mathbf{P}$ & \\
\hline \multirow{5}{*}{ Bilgi Edinme } & 1.ilköğretim & 4 & 7,75 & 3,77 & $\begin{array}{l}\text { Gruplar } \\
\text { Arasi }\end{array}$ & 163,29 & 4 & $\begin{array}{c}40,8 \\
2\end{array}$ & \multirow{5}{*}{$\begin{array}{c}4,5 \\
4\end{array}$} & \multirow{5}{*}{$\begin{array}{c}0,00 \\
*\end{array}$} & \\
\hline & 2. lise & 29 & $\begin{array}{c}12,0 \\
0\end{array}$ & 2,83 & Gruplar İçi & 3345,48 & $\begin{array}{c}37 \\
2\end{array}$ & 8,99 & & & $5-4$ \\
\hline & 3. ön lisans & 71 & $\begin{array}{c}11,3 \\
7\end{array}$ & 2,79 & Toplam & 3508,77 & $\begin{array}{c}37 \\
6\end{array}$ & & & & $5-1$ \\
\hline & 4. lisans & $\begin{array}{c}23 \\
8\end{array}$ & $\begin{array}{c}10,7 \\
4\end{array}$ & 3,16 & & & & & & & \\
\hline & 5. lisansüstü & 35 & $\begin{array}{c}12,4 \\
0\end{array}$ & 2,26 & & & & & & & \\
\hline \multirow{5}{*}{$\begin{array}{c}\text { Paylaşım ve } \\
\text { Aidiyet }\end{array}$} & 1. ilköğretim & 4 & $\begin{array}{c}11,7 \\
5\end{array}$ & 5,32 & $\begin{array}{l}\text { Gruplar } \\
\text { Arasi }\end{array}$ & 387,54 & 4 & $\begin{array}{c}96,8 \\
9\end{array}$ & \multirow{5}{*}{$\begin{array}{c}3,2 \\
0\end{array}$} & \multirow{5}{*}{$\begin{array}{c}0,01 \\
*\end{array}$} & \\
\hline & 2. lise & 29 & $\begin{array}{c}17,1 \\
4\end{array}$ & 4,52 & Gruplar İçi & $\begin{array}{c}11208,4 \\
5\end{array}$ & $\begin{array}{c}37 \\
0\end{array}$ & $\begin{array}{c}30,2 \\
9\end{array}$ & & & \\
\hline & 3. ön lisans & 71 & $\begin{array}{c}15,1 \\
3\end{array}$ & 6,44 & Toplam & $\begin{array}{c}11595,9 \\
9\end{array}$ & $\begin{array}{c}37 \\
4\end{array}$ & & & & \\
\hline & 4. lisans & $\begin{array}{c}23 \\
6\end{array}$ & $\begin{array}{c}14,4 \\
5\end{array}$ & 5,33 & & & & & & & \\
\hline & 5. lisansüstü & 35 & $\begin{array}{c}17,0 \\
0\end{array}$ & 5,35 & & & & & & & \\
\hline \multirow{5}{*}{$\begin{array}{l}\text { Etkileşim ve } \\
\text { Güvenme }\end{array}$} & 1. ilköğretim & 4 & $\begin{array}{c}15,2 \\
5\end{array}$ & 4,50 & $\begin{array}{l}\text { Gruplar } \\
\text { Arasi }\end{array}$ & 328,51 & 4 & $\begin{array}{c}82,1 \\
3\end{array}$ & \multirow{5}{*}{$\begin{array}{c}4,0 \\
8\end{array}$} & \multirow{5}{*}{$\begin{array}{c}0,00 \\
*\end{array}$} & \\
\hline & 2. lise & 29 & $\begin{array}{c}18,7 \\
6\end{array}$ & 3,99 & Gruplar İçi & 7466,11 & $\begin{array}{c}37 \\
1\end{array}$ & $\begin{array}{c}20,1 \\
2\end{array}$ & & & $5-4$ \\
\hline & 3. ön lisans & 72 & $\begin{array}{c}17,6 \\
7\end{array}$ & 4,50 & Toplam & 7794,61 & $\begin{array}{c}37 \\
5\end{array}$ & & & & \\
\hline & 4. lisans & $\begin{array}{c}23 \\
6 \\
\end{array}$ & $\begin{array}{c}16,8 \\
3 \\
\end{array}$ & 4,70 & & & & & & & \\
\hline & 5. lisansüstü & 35 & $\begin{array}{c}19,6 \\
3\end{array}$ & 3,14 & & & & & & & \\
\hline \multirow{5}{*}{ Yararlanma } & 1. ilköğretim & 4 & $\begin{array}{c}22,7 \\
5\end{array}$ & 3,20 & $\begin{array}{l}\text { Gruplar } \\
\text { Arası }\end{array}$ & 295,78 & 4 & $\begin{array}{c}73,9 \\
4\end{array}$ & \multirow{5}{*}{$\begin{array}{c}2,2 \\
6\end{array}$} & \multirow{5}{*}{0,06} & \\
\hline & 2. lise & 29 & $\begin{array}{c}22,9 \\
7\end{array}$ & 5,68 & Gruplar İçi & $\begin{array}{c}11987,4 \\
8\end{array}$ & $\begin{array}{c}36 \\
7\end{array}$ & $\begin{array}{c}32,6 \\
6\end{array}$ & & & \\
\hline & 3. ön lisans & 69 & $\begin{array}{c}22,1 \\
2 \\
\end{array}$ & 6,12 & Toplam & $\begin{array}{c}12283,2 \\
6\end{array}$ & $\begin{array}{c}37 \\
1 \\
\end{array}$ & & & & \\
\hline & 4. lisans & $\begin{array}{c}23 \\
6 \\
\end{array}$ & $\begin{array}{c}21,6 \\
3 \\
\end{array}$ & 5,82 & & & & & & & \\
\hline & 5. lisansüstü & 34 & $\begin{array}{c}24,6 \\
5\end{array}$ & 4,10 & & & & & & & \\
\hline Çelişki & 1. ilköğretim & 4 & 21,0 & 6,22 & Gruplar & 314,58 & 4 & 78,6 & 2,9 & 0,02 & \\
\hline
\end{tabular}




\begin{tabular}{|c|c|c|c|c|c|c|c|c|c|c|c|}
\hline & & & 0 & & Arası & & & 5 & \multirow[t]{5}{*}{0} & \multirow[t]{5}{*}{$*$} & \\
\hline & 2. lise & 29 & $\begin{array}{c}13,9 \\
7 \\
\end{array}$ & 4,93 & Gruplar İçi & 9957,90 & $\begin{array}{c}36 \\
7 \\
\end{array}$ & $\begin{array}{c}27,1 \\
3 \\
\end{array}$ & & & $5-1$ \\
\hline & 3. ön lisans & 71 & $\begin{array}{c}14,9 \\
4 \\
\end{array}$ & 5,38 & Toplam & $\begin{array}{c}10272,4 \\
8\end{array}$ & $\begin{array}{c}37 \\
1 \\
\end{array}$ & & & & \\
\hline & 4. lisans & $\begin{array}{c}23 \\
3\end{array}$ & $\begin{array}{c}14,7 \\
6\end{array}$ & 5,26 & & & & & & & \\
\hline & 5. lisansüstü & 35 & $\begin{array}{c}12,7 \\
1 \\
\end{array}$ & 4,60 & & & & & & & \\
\hline \multirow{5}{*}{ Kullanım } & 1. ilköğretim & 4 & $\begin{array}{c}17,2 \\
5\end{array}$ & 7,54 & $\begin{array}{l}\text { Gruplar } \\
\text { Arası }\end{array}$ & 235,63 & 4 & $\begin{array}{c}58,9 \\
1 \\
\end{array}$ & \multirow{5}{*}{$\begin{array}{c}1,6 \\
0\end{array}$} & \multirow{5}{*}{0,18} & \\
\hline & 2. lise & 28 & $\begin{array}{c}20,5 \\
0\end{array}$ & 4,93 & Gruplar İçi & $\begin{array}{c}13404,8 \\
5\end{array}$ & $\begin{array}{c}36 \\
3\end{array}$ & $\begin{array}{c}36,9 \\
3\end{array}$ & & & \\
\hline & 3. ön lisans & 72 & $\begin{array}{c}19,3 \\
5\end{array}$ & 5,69 & Toplam & $\begin{array}{c}13640,4 \\
8 \\
\end{array}$ & $\begin{array}{c}36 \\
7 \\
\end{array}$ & & & & \\
\hline & 4. lisans & $\begin{array}{c}22 \\
8 \\
\end{array}$ & $\begin{array}{c}18,0 \\
4 \\
\end{array}$ & 6,14 & & & & & & & \\
\hline & 5. lisansüstü & 36 & $\begin{array}{c}19,2 \\
8\end{array}$ & 7,00 & & & & & & & \\
\hline \multirow{5}{*}{$\begin{array}{c}\text { Firmalara } \\
\text { Yönelik } \\
\text { Değerlendir } \\
\text { me }\end{array}$} & 1. ilköğretim & 4 & $\begin{array}{c}21,7 \\
5\end{array}$ & 7,09 & $\begin{array}{l}\text { Gruplar } \\
\text { Arası }\end{array}$ & 243,19 & 4 & $\begin{array}{c}60,8 \\
0\end{array}$ & \multirow{5}{*}{$\begin{array}{c}2,1 \\
6\end{array}$} & \multirow{5}{*}{0,07} & \\
\hline & 2. lise & 29 & $\begin{array}{c}23,7 \\
9\end{array}$ & 5,56 & Gruplar İçi & $\begin{array}{c}10495,5 \\
8\end{array}$ & $\begin{array}{c}37 \\
2\end{array}$ & $\begin{array}{c}28,2 \\
1\end{array}$ & & & \\
\hline & 3. ön lisans & 72 & $\begin{array}{c}22,7 \\
4\end{array}$ & 5,42 & Toplam & $\begin{array}{c}10738,7 \\
7\end{array}$ & $\begin{array}{c}37 \\
6\end{array}$ & & & & \\
\hline & 4. lisans & $\begin{array}{c}23 \\
7\end{array}$ & $\begin{array}{c}22,5 \\
6\end{array}$ & 5,39 & & & & & & & \\
\hline & 5. lisansüstü & 35 & $\begin{array}{c}25,2 \\
0\end{array}$ & 3,93 & & & & & & & \\
\hline \multirow{5}{*}{$\begin{array}{c}\text { Genel } \\
\text { Değerlendir } \\
\text { me }\end{array}$} & 1. ilköğretim & 4 & $\begin{array}{c}15,7 \\
5 \\
\end{array}$ & 3,50 & $\begin{array}{l}\text { Gruplar } \\
\text { Arası }\end{array}$ & 187,20 & 4 & $\begin{array}{c}46,8 \\
0 \\
\end{array}$ & \multirow{5}{*}{$\begin{array}{c}3,1 \\
9\end{array}$} & \multirow{5}{*}{$\begin{array}{c}0,01 \\
*\end{array}$} & \\
\hline & 2. lise & 28 & $\begin{array}{c}16,2 \\
5 \\
\end{array}$ & 2,66 & Gruplar İçi & 5475,95 & $\begin{array}{c}37 \\
3 \\
\end{array}$ & $\begin{array}{c}14,6 \\
8 \\
\end{array}$ & & & $2-4$ \\
\hline & 3. ön lisans & 72 & $\begin{array}{c}15,0 \\
1 \\
\end{array}$ & 3,78 & Toplam & 5663,14 & $\begin{array}{c}37 \\
7\end{array}$ & & & & \\
\hline & 4. lisans & $\begin{array}{c}23 \\
8\end{array}$ & $\begin{array}{c}14,1 \\
3\end{array}$ & 3,98 & & & & & & & \\
\hline & 5. lisansüstü & 36 & $\begin{array}{c}15,6 \\
7\end{array}$ & 3,70 & & & & & & & \\
\hline
\end{tabular}

\section{${ }^{*} \mathrm{p}<0,05$}

Tablo 3'te turizm tüketicilerinin eğitim grubu üzerinden, paylaşım ve aidiyet, yararlanma, kullanım ve firmalara yönelik değerlendirme alt boyutları arasında anlamlı bir farklılık tespit edilememiştir. Bilgi edinme, etkileşim ve güvenme, çelişki ve genel değerlendirme ölçek alt boyutları arasında ise anlamlı bir farklılık tespit edilmiştir. Bu durumu ayrıntılı ele almak gerekirse;

Bilgi edinme alt boyutunda lisansüstü ve lisans, lisansüstü ve ilköğretim arasında anlamlı bir fark olduğu tespit edilmiştir. Bu durum, turizm tüketicilerinin seyahat araştırması ve otel 
seçimi noktasında sosyal paylaşım siteleri üzerinden bilgi edinirken, lisansüstü eğitim alan kişilerin daha aktif şekilde sosyal paylaşım sitesini kullandıklarını göstermektedir.

Etkileşim ve güvenme alt boyutunda lisansüstü ve lisans arasında anlamlı bir fark tespit edilmiştir. Bu durumda da lisansüstü eğitim alan kişilerin sosyal paylaşım sitelerini kullanarak, seyahat araştırması hususunda etkileşime girmiş olduklarını ve bu etkileşim sonucunda da tüketicilerde bir güven duygusu oluştuğunu göstermektedir.

Çelişki alt boyutunda lisansüstü ve ilköğretim arasında anlamlı bir fark tespit edilmiştir. Burada da yine lisansüstü eğitim alan grubun sosyal paylaşım sitelerini turizm noktasında kullanırken daha az çelişki duyduğunu göstermektedir. Bu aynı zamanda etkileşim ve güvenme alt boyutu ile ilişkilendirilebilir.

Genel değerlendirmede ise lise ve lisans arasında anlamlı bir fark tespit edilmiştir. Bu durum sosyal paylaşım sitelerinin, özellikle cep telefonu ve internetin aktif kullanımı ile açıklanabilir, çünkü günümüz lise ve üniversite genelinde yer alan tüketici grubu, sosyal medya ve internet kullanımı noktasında oldukça aktiftir. Dolayısıyla, sosyal paylaşım sitelerinde turizm tüketimi üzerine yapılan reklam ve tanıtım stratejileri gerçekleştirilmeye başlayınca, lise düzeyinde bulunanların ardından, lisans düzeyinde bulunanların da genel olarak turizm tüketiminde sosyal paylaşım sitelerini diğer eğitim gruplarına nazaran daha aktif kullandıkları görülmektedir.

Tablo 4. Yaş Grupları Üzerinden Ölçek Alt Boyutlarının Karşılaştıııldığı ANOVA Testi Sonuçları

\begin{tabular}{|c|c|c|c|c|c|c|c|c|c|c|}
\hline & & & & & \multicolumn{6}{|c|}{ ANOVA } \\
\hline Değişken & Grup & $\mathbf{N}$ & & $S$ & & KT & dff & KO & $\mathbf{F}$ & $p$ \\
\hline \multirow{5}{*}{ Bilgi Edinme } & 1.20 Yaş ve Altı & 26 & 10,96 & 2,85 & $\begin{array}{l}\text { Gruplar } \\
\text { Aras1 }\end{array}$ & 3,50 & 4 & 0,87 & \multirow{5}{*}{0,09} & \multirow{5}{*}{0,99} \\
\hline & 2. 21-30 Yaş & 240 & 11,13 & 2,92 & Gruplar İçi & 3505,27 & 372 & 9,42 & & \\
\hline & 3. 31-40 Yaş & 72 & 11,10 & 3,10 & Toplam & 3508,77 & 376 & & & \\
\hline & 4. 41-50 Yaş & 23 & 10,83 & 3,85 & & & & & & \\
\hline & 5.51 Yaş ve Üstü & 16 & 10,81 & 4,07 & & & & & & \\
\hline \multirow{5}{*}{$\begin{array}{c}\text { Paylaşım ve } \\
\text { Aidiyet }\end{array}$} & 1. 20 Yaş ve Altı & 26 & 14,69 & 5,53 & $\begin{array}{l}\text { Gruplar } \\
\text { Arası }\end{array}$ & 92,36 & 4 & 23,09 & \multirow{5}{*}{0,75} & \multirow{5}{*}{0,56} \\
\hline & 2. 21-30 Yaş & 240 & 15,24 & 5,41 & Gruplar İçi & 11403,26 & 369 & 30,90 & & \\
\hline & 3. 31-40 Yaş & 70 & 14,03 & 5,70 & Toplam & 11495,62 & 373 & & & \\
\hline & 4. 41-50 Yaş & 23 & 14,78 & 6,51 & & & & & & \\
\hline & 5.51 Yaş ve Üstü & 15 & 15,80 & 5,82 & & & & & & \\
\hline \multirow{5}{*}{$\begin{array}{l}\text { Etkileşim Ve } \\
\text { Güvenme }\end{array}$} & 1. 20 Yaş ve Altı & 26 & 16,81 & 5,22 & \begin{tabular}{|l} 
Gruplar \\
Arasi
\end{tabular} & 64,80 & 4 & 16,20 & \multirow{5}{*}{0,78} & \multirow{5}{*}{0,54} \\
\hline & 2. 21-30 Yaş & 238 & 17,63 & 4,06 & Gruplar İçi & 7671,60 & 370 & 20,73 & & \\
\hline & 3. 31-40 Yaş & 71 & 16,99 & 5,48 & Toplam & 7736,40 & 374 & & & \\
\hline & 4. 41-50 Yaş & 23 & 17,26 & 5,55 & & & & & & \\
\hline & 5.51 Yaş ve Üstü & 17 & 16,06 & 4,45 & & & & & & \\
\hline \multirow{4}{*}{ Yararlanma } & 1. 20 Yaş ve Altı & 26 & 20,96 & 6,47 & \begin{tabular}{|l|l|} 
Gruplar \\
Arasi
\end{tabular} & 130,23 & 4 & 32,56 & \multirow{4}{*}{0,98} & \multirow{4}{*}{0,42} \\
\hline & 2. 21-30 Yaş & 237 & 22,53 & 5,34 & Gruplar İçi & \begin{tabular}{|l|}
12153,03 \\
\end{tabular} & 367 & 33,12 & & \\
\hline & 3. 31-40 Yaş & 71 & 21,30 & 6,56 & Toplam & 12283,26 & 371 & & & \\
\hline & 4. 41-50 Yaş & 23 & 22,13 & 6,84 & & & & & & \\
\hline
\end{tabular}




\begin{tabular}{|c|c|c|c|c|c|c|c|c|c|c|}
\hline & 5.51 Yaş ve Üstü & 15 & 21,40 & 4,94 & & & & & & \\
\hline \multirow{5}{*}{ Çelişki } & 1. 20 Yaş ve Altı & 26 & 15,42 & 5,68 & $\begin{array}{l}\text { Gruplar } \\
\text { Arası }\end{array}$ & 99,52 & 4 & 24,88 & \multirow{5}{*}{0,92} & \multirow{5}{*}{0,45} \\
\hline & 2. 21-30 Yaş & 238 & 14,41 & 5,12 & Gruplar İçi & 9935,48 & 366 & 27,15 & & \\
\hline & 3. $31-40 \mathrm{Yaş}$ & 70 & 14,51 & 5,01 & Toplam & 10035,00 & 370 & & & \\
\hline & 4. 41-50 Yaş & 23 & 14,09 & 5,37 & & & & & & \\
\hline & $\begin{array}{l}\text { 5. } 51 \text { Yaş ve } \\
\text { Üstü }\end{array}$ & 14 & 16,79 & 6,52 & & & & & & \\
\hline \multirow{5}{*}{ Kullanım } & 1. 20 Yaş ve Altı & 25 & 19,24 & 5,88 & $\begin{array}{l}\text { Gruplar } \\
\text { Arası }\end{array}$ & 246,09 & 4 & 61,52 & \multirow{5}{*}{1,67} & \multirow{5}{*}{0,16} \\
\hline & 2. $21-30$ Yaş & 233 & 19,11 & 5,57 & Gruplar İçi & 13394,39 & 363 & 36,90 & & \\
\hline & 3. $31-40$ Yaş & 71 & 17,20 & 7,51 & Toplam & 13640,48 & 367 & & & \\
\hline & 4. 41-50 Yaş & 23 & 17,52 & 6,77 & & & & & & \\
\hline & 5.51 Yaş ve Üstü & 16 & 17,88 & 5,25 & & & & & & \\
\hline \multirow{5}{*}{$\begin{array}{c}\text { Firmalara } \\
\text { Yönelik } \\
\text { Değerlendirme }\end{array}$} & 1. 20 Yaş ve Altı & 26 & 22,38 & 5,82 & $\begin{array}{l}\text { Gruplar } \\
\text { Arası }\end{array}$ & 172,43 & 4 & 43,11 & \multirow{5}{*}{1,52} & \multirow{5}{*}{0,20} \\
\hline & 2. 21-30 Yaş & 239 & 23,11 & 4,97 & Gruplar İçi & 10516,12 & 371 & 28,35 & & \\
\hline & 3. $31-40$ Yaş & 71 & 21,75 & 6,14 & Toplam & 10688,55 & 375 & & & \\
\hline & 4. 41-50 Yaş & 23 & 24,39 & 5,58 & & & & & & \\
\hline & 5.51 Yaş ve Üstü & 17 & 23,65 & 5,48 & & & & & & \\
\hline \multirow{5}{*}{$\begin{array}{c}\text { Genel } \\
\text { Değerlendirme }\end{array}$} & 1. 20 Yaş ve Altı & 26 & 14,50 & 3,84 & $\begin{array}{l}\text { Gruplar } \\
\text { Arası }\end{array}$ & 125,85 & 4 & 31,46 & \multirow{5}{*}{2,12} & \multirow{5}{*}{0,08} \\
\hline & 2. $21-30$ Yaş & 240 & 14,95 & 3,56 & Gruplar İçi & 5537,29 & 373 & 14,85 & & \\
\hline & 3. $31-40$ Yaş & 72 & 13,50 & 4,62 & Toplam & 5663,14 & 377 & & & \\
\hline & 4. 41-50 Yaş & 23 & 15,09 & 4,50 & & & & & & \\
\hline & 5.51 Yaş ve Üstü & 17 & 14,18 & 3,30 & & & & & & \\
\hline
\end{tabular}

Tablo 4'te ölçek alt boyutlarının yaş grupları üzerinden tek yönlü varyans analizlerinin karşılaştırıldığı görülmektedir. Yapılan analizler sonucunda ise alt boyutların hiçbirinde yaş grupları arasında anlamlı bir farklılık tespit edilememiştir. Bu durumu, çalışmaya dâhil edilen katılımcıların sosyal paylaşım sitelerine ayırmış oldukları zamanda yüksek bir fark bulunamamasından kaynaklandığı söylenebilir.

Tablo 5. Cinsiyet Grupları Üzerinden Anket Alt Boyutlarının Karşılaştırıldı ̆̆̆ T-Testi Sonuçları

\begin{tabular}{|c|c|c|c|c|c|c|c|}
\hline Alt Boyutlar & Grup & $\mathbf{N}$ & $\overline{\boldsymbol{x}}$ & $S$ & $t$ & sd & $\mathbf{p}$ \\
\hline \multirow{2}{*}{ Bilgi Edinme } & Erkek & 169 & 10,33 & 3,22 & \multirow{2}{*}{4,37} & \multirow{2}{*}{375} & \multirow{2}{*}{0,00} \\
\hline & Kadın & 208 & 11,68 & 2,78 & & & \\
\hline \multirow{2}{*}{ Paylaşım ve Aidiyet } & Erkek & 169 & 14,01 & 5,57 & \multirow{2}{*}{3,15} & \multirow{2}{*}{373} & \multirow{2}{*}{0,00} \\
\hline & Kadın & 206 & 15,81 & 5,45 & & & \\
\hline \multirow{2}{*}{ Etkileşim ve Güvenme } & Erkek & 170 & 16,68 & 4,91 & \multirow{2}{*}{2,72} & \multirow{2}{*}{374} & \multirow{2}{*}{0,00} \\
\hline & Kadın & 206 & 17,96 & 4,17 & & & \\
\hline \multirow{2}{*}{ Yararlanma } & Erkek & 169 & 21,11 & 6,28 & \multirow{2}{*}{3,11} & \multirow{2}{*}{370} & \multirow{2}{*}{0,01} \\
\hline & Kadın & 203 & 22,95 & 5,14 & & & \\
\hline Çelişki & Erkek & 168 & 15,34 & 5,41 & $-2,44$ & 370 & 0,05 \\
\hline
\end{tabular}




\begin{tabular}{|c|c|c|c|c|c|c|c|}
\hline & Kadın & 204 & 14,01 & 5,07 & & & \\
\hline \multirow{2}{*}{ Kullanım } & Erkek & 170 & 17,71 & 6,34 & \multirow{2}{*}{2,62} & \multirow{2}{*}{366} & \multirow{2}{*}{0,01} \\
\hline & Kadın & 198 & 19,36 & 5,79 & & & \\
\hline \multirow{2}{*}{$\begin{array}{l}\text { Firmalara Yönelik } \\
\text { Değerlendirme }\end{array}$} & Erkek & 171 & 22,11 & 5,77 & \multirow{2}{*}{2,73} & \multirow{2}{*}{375} & \multirow{2}{*}{0,01} \\
\hline & Kadın & 206 & 23,60 & 4,87 & & & \\
\hline \multirow{2}{*}{ Genel Değerlendirme } & Erkek & 171 & 13,56 & 4,09 & \multirow{2}{*}{5,00} & \multirow{2}{*}{376} & \multirow{2}{*}{0,00} \\
\hline & Kadın & 207 & 15,50 & 3,46 & & & \\
\hline
\end{tabular}

${ }^{*} \mathrm{p}<0,05$ (anlamlı fark)

Tablo 5'te turizm tüketicilerinin sosyal paylaşım sitelerine yönelik algılarının cinsiyete göre anlamlı bir farklılığının olup olmadığı T-testi ile analiz edilmiştir. Bu bağlamda, ölçek alt boyutlarının karşılaştırılmasında bilgi edinme, paylaşım ve aidiyet, etkileşim ve güvenme, yararlanma, kullanım, firmalara yönelik değerlendirme ve genel değerlendirmede kadınların lehine, çelişki alt boyutunda ise erkeklerin lehine anlamlı bir fark tespit edilmiştir $(p<0,05)$.

\section{SONUÇ VE ÖNERILLER}

Sınırsız ifade olanağı sunan sosyal medyanın, birçok endüstri ile birlikte turizm endüstrisinin de değişimine öncülük ettiği görülmektedir. Sosyal medyanın insan hayatında büyük bir yer edinmesi ile turizm endüstrisi tarafından sosyal paylaşım sitelerine dâhil olmanın önemi fark edilmiştir. Bu bakımdan işletmelerin sosyal medya araçlarından olan sosyal paylaşım sitelerine dâhil olması, pazarlama anlayışında yeni bir devrin başladığının göstergesidir. Böylelikle pazarlama stratejilerinin uygulanmasında farklı bir boyut oluşturan sosyal medya, içeriği bakımından hızlı, ekonomik ve etkilidir.

İşletmeler, sosyal medyada yer edinebilmek için aktif olarak katılım göstermeli ve tüketicilerle dinamik bir iletişim ortamı kurmalıdır. Yeni nesil bilinçli tüketiciler, sosyal medyada paylaşılan deneyim ve bilgiler aracılığılyla düşüncelerine yön vermektedir. Bu bakımdan işletmeler, sosyal mecralarda tüketicilerin istek ve ihtiyaçlarına cevap vererek, onlarla doğrudan iletişime geçmektedir. Böylelikle, tüketiciler tarafından geri bildirimin sağlanması işletmelere etkili içerik oluşturma ve pazarlama stratejilerini geliştirme konusunda fayda sağlayacaktır. Bu bağlamda sosyal medya pazarlaması sadece ürün satışlarını artırmamakta, ayrıca potansiyel tüketicileri de harekete geçirmektedir.

Sosyal paylaşım siteleri aracılığıyla reklam ve pazarlama kampanyalarını gerçekleştiren otel işletmelerinin aktif olarak sosyal medyada yer alması, turizm tüketicileri tarafından tercih edilebilirlik oranının artmasını sağlamaktadır. Aynı zamanda turizm tüketicilerinin, popülerliği yüksek sosyal paylaşım sitelerinden olan Facebook ve Instagram'da daha çok vakit geçiriyor olması, işletmelerin daha yaratıcı ve akılda kalıcı pazarlama fikirlerinin ortaya çıkması gerektiği gerçeğiyle yüzleştiği söylenebilir. Bu bağlamda işletmeler, sosyal medya pazarlamasında hashtag kullanarak paylaşımları belli bir anahtar kelime ile kategorize edip, bilgiye daha net ve hızlı ulaşmayı kolay hale getirmektedir. Bu sayede otel işletmelerinin, turizm tüketicilerini etkileme ve harekete geçirme payını elde ettiği ifade edilebilir. 
Turizm tüketicilerinin;

- Facebook ve Instagram'da otel işletmeleri hakkında yapılan yorum ve değerlendirmelerden olumlu yönde etkilendikleri,

- Bilgi edinme, seyahatlerini daha iyi planlama ve kolay karar verme amacı ile sosyal medyadan yararlandikları,

- Keşfetme, kullanım, kolay erişim, sosyal statü elde etme ve yarar sağlama gibi niyetler ile sosyal paylaşım sitelerini kullandıkları ifade edilebilir.

Araştırma kapsamında elde edilen verilerin analiz edilmesi sonucunda bazı öneriler sunulmuştur:

Otel işletmelerine öneriler

- İlk etapta rakip otel işletmelerinin sosyal medya üzerinden yürüttüğü stratejilerin yakından takip edilmesi gerekmektedir.

- Yaratıcı ve ilgi çekici içeriklerin sosyal paylaşım siteleri üzerinden paylaşılması ile turizm tüketicilerinin merakı daha da artırılabilir.

- Otel tanıtımına destek olacak görsel ve videoların düzenli aralıklarla paylaşılması sayfanın aktif olarak gelişebilmesine katkı sağlayacaktır.

- Özgün fikirlerle hazırlanan içeriklerin paylaşılması, otel işletmesinin tüketicileriyle olan güven bağını sağlamlaştırılmasında önemli bir adım olabilir.

- Turizm tüketicileri tarafından yapılan yorum ve değerlendirmelere otel işletmeleri tarafından hızlı geri dönüş ve samimi cevaplar ile karşılık verilmesi işletme imajının önem kazanması bakımından dikkate alınması gereken bir öneri olabilir.

- Otel işletmelerinin daima değişimde açık yapıya sahip olmaları ve sektördeki yenilikleri takip etmeleri yararlı olacaktır.

- Oteller için özel oluşturulmuş marka değerini yansıtan hashtag'lere yapılan paylaşımlarda yer verilmesi kitlelere daha hızlı erişim imkânı sağlayacaktır.

- Turizm tüketicileri, işletme ile ilgili paylaşım ve yorumlar yapmaları amacıyla çeşitli çekiliş ve yarışmalar ile teşvik edilebilir.

- Özel gün indirimleri ve çeşitli kampanyalar hakkında detaylı bilgi verici paylaşımlar turizm tüketicileri arasındaki etkileşimi daha da artırabilir.

- Ulaşım ve konaklamaya dair izlenilmesi gereken yolların net bir şekilde keyif veren içerikler oluşturarak anlatılması, tercih edilebilir olmayı sağlayabilir.

- Sosyal medya pazarlamasında başarı gösterilebilmesi için sosyal medya uzmanlarından profesyonel destek alınması önerilebilir.

\section{Turizm tüketicilerine öneriler}

- Sosyal medyanın çok boyutlu bir mecra olduğu aşikârdır. Bu nedenle sosyal medya platformlarında birçok yasal ve yasa dışı sayfa ve siteler mevcuttur. Turizm tüketicilerinin de seyahat planlaması sürecinde, otel araştırması yaparken bilginin doğruluğundan emin olmadan seçimde bulunmamaları tavsiye edilebilir.

- Konaklanılan otel işletmesi hakkındaki deneyim ve tecrübelerin tüketiciler tarafından sosyal medya hesaplarında paylaşılması, o işletme için destek oluşturabilir. Bununla birlikte paylaşımlarda otel markasını yansıtan hashtag'lerin kullanılması daha fazla kişi ile etkileşime geçilmesi noktasında katkı sağlayabilir. 
- Turizm tüketicileri, turizm işletmelerinin dikkatini çekmek adına daha yararlı ve güvenilir bilgiler elde etme isteklerini potansiyel turizm tüketicileri ile kamuoyu oluşturarak sosyal medyadan duyurabilir.

- Tercih edilen otel işletmesi sayfasını takip etmek, beğeni ve yorumlar ile katkı sağlamak önerilebilir.

Yer verilen öneriler dahilinde, ilerleyen süreçlerde yapılacak olan çalışmalar içinse sosyal medyanın farklı platformları da dikkate alınarak tüketici seçimlerinin incelenmesi gerekliliğini vurgulamak mümkündür.

\section{KAYNAKÇA}

Ahmad, N. S., Musa, R. ve Harun, M. H., (2016). The impact of social media content marketing (SMCM) towards brand health. Procedia Economics and Finance, 37(16), 331-336.

Alagöz, G., Dereli, A. N. (2020). Kış turizmi koridoru'ndaki otel işletmelerinin sosyal medya kullanımlarına ilişkin bir araştırma. Journal of Tourism and Gastronomy Studies, 8(4), 2802-2824.

Altınay Bor, H. (2018). Ergenlerde sosyal medyaya yönelik tutum, sosyal medya kullanımında gelişmeleri kaçırma korkusu ve sosyal kayg̨ arasındaki ilişkiler. Yayımlanmamış yüksek lisans tezi, İstanbul Üniversitesi, Eğitim Bilimleri Enstitüsü, İstanbul.

Araştırma yöntem ve tekniklerinin seçimi. 17 Aralık 2020 tarihinde http://www.bingol.edu.tr/ media/205521/sayt-bolum9-Arastirma-Yontem-ve-Tekniklerinin-Secimi.pdf adresinden erişildi.

Arat, T., Dursun, G. (2016). Seyahat ve konaklama tercihi açısından sosyal paylaşım sitelerinin kullanımı. Selçuk Üniversitesi Sosyal Bilimler Meslek Yüksekokulu Dergisi, 19(41), 111-128.

Atadil, H. A. (2011). Otel işletmelerinde sosyal medya pazarlamast: turizm tüketicilerinin sosyal paylaşım sitelerine ilişkin algıları üzerine bir alan çalışması. Yayımlanmamış yüksek lisans tezi, Dokuz Eylül Üniversitesi, Sosyal Bilimler Enstitüsü, İzmir.

Buzlukçu, C., Kılıç, B. (2015). Butik ve küçük otel işletmelerinde sosyal medya kullanımı ve yöneticilerin sosyal medyaya bakışı. 16. Ulusal Turizm Kongresi Bildiriler Kitabı, 12-15 Kasım 2015, Çanakkale s.535-547.

Dwityas, N. A. ve Briandana, R. (2017). Social media in travel decision making process. International Journal of Humanities and Social Science, 7(7), 193-201.

Eryılmaz, B., Zengin, B. (2014). Butik otel işletmelerinin sosyal medya kullanımına yönelik bir inceleme: Facebook örneği. Kastamonu Üniversitesi İktisadi ve İdari Bilimler Fakültesi Dergisi, 4, 42-59.

Firat, D. (2017). Sosyal medya pazarlaması.İstanbul: Beta Yayınevi. 
Güçdemir, Y. (2017). Sosyal medya halkla ilişkiler, reklam ve pazarlama. (1. Baskı). İstanbul: Derin Yayınevi.

Kaplan, A. M. ve Haenlein, M. (2010). Users of the world, unite! The challenges and opportunities of social media. Business Horizons, 53(1), 59-68.

Karamehmet, B., Aydın, G. (2017). Turizm sektöründe sosyal medya kullanım etkinliğinin iyileştirilmesi: 5 yıldızlı oteller üzerinde bir çalışma. Uluslararası İktisadi ve İdari Incelemeler Dergisi, 16, 593-606.

Liu, Y., Zhang, L. ve Yan Cao, S. (2018). An mediated effect analysis of purchasing intention under social media from the Chinese motion industry. International Journal of Economics, Finance and Management Sciences, 6(3), 124-132.

Neti, S. (2011). Social media and its role in marketing. International Journal of Enterprise Computing and Business Systems, 1(2), 1-15.

Oberoi, P., Patel, C. ve Haon, C. (2017). Technology sourcing for website personalization and social media marketing: A study of e-retailing industry. Journal of Business Research, 80, $10-23$.

Rathore, A. K., Joshi, U. ve Ilavarasan, P. (2017). Social media usage for tourism: A case of rajasthan tourism. Procedia Computer Science, 122, 751-758.

Xiang, Z. ve Gretzel, U. (2010). Role of social media in online travel information search. Tourism Management, 31(2), 179-188.

Yeşildal, G. (2017). Hazır giyim ürünlerinin sosyal medya üzerinden satın alınmasında tüketici algısının rolü (Instagram örneği). Yayımlanmamış yüksek lisans tezi, Gelişim Üniversitesi, Sosyal Bilimler Enstitüsü, İstanbul.

Yıldız, D., Uzunsakal, E. (2018). Alan araştırmalarında güvenilirlik testlerinin karşılaştırılması ve tarımsal veriler üzerine bir uygulama. Uygulamalı Sosyal Bilimler Dergisi, 1, 14-28.

Yılmazdoğan, O. C., Özel, Ç. H. (2014). Sosyal medya pazarlamasının otellerdeki kullanımının yararlarına yönelik yönetici algılarının belirlenmesi: Antalya örneği. İşletme Fakültesi Dergisi, 15(1), 37-62.

Zeng, B. ve Gerritsen, R. (2014). What do we know about social media in tourism? A review. Tourism Management Perspectives, (10), 27-36.

Zerfass, A. Moreno, A. Tench, R. Vercic, D. ve Verhoeven, P. (2009). European communication monitor. Trends in Communication Management and Public Relations - Results of a Survey in 34 Countries, Brussels: EACD, Euprera.

2020 Türkiye internet kullanımı ve sosyal medya istatistikleri. 13 Aralı 2020 tarihinde https://dijilopedi.com/2020-turkiye-internet-kullanimi-ve-sosyal-medyaistatistikleri/ adresinden erişildi. 